\section{Popper: success or failure?}

SIR - Popper's own estimation of himself does not square with Bondi's'. "Here I [Sir Karl Popper] am being showered with honours as no professional philosopher before me; yet three generations of professional philosophers know nothing about my work"2.

Popper is a remarkable philosopher, but his success - and failure - is even more remarkable. Most human existence has been in closed societies. We are lucky: we live in an open society. Popper more than anybody this century has made us aware of its importance, and its relationship with science. $\mathrm{He}$ has also shown that both owe their existence to critical debate and to our collective preparedness, as citizens and scientists, to reason, debate, conjecture and criticize ideas.

But he has also failed. Popper notes that the Greeks invented the tradition of critical debate and the open society ${ }^{3}$. But from Popper, no tradition has arisen for their study. There is no school of Popper: the only popperians are scientists, like Bondi, not philosophers or those studying society.

Indeed, Popper's failure has been worse. There has been another equally remarkable story: the rise in much of contemporary philosophy and sociology of the conclusion that criticism and open debate are of little or no importance, either in society or science. Instead, scholars of science widely attribute its success, together with that of our open society, to such things as political power, ideologies, and 'social contingencies'. Does the failure of Popper's ideas among those studying science and society matter? I think it does. I focus upon its relevance to science.

(1) Popper and the contemporary study of science cannot both be right. One of them has to be outlandishly wrong. This disjunction is ignored but it should be faced. There is no necessary reason to respect all scholarship. If Popper is right, then the study of science has to be a study of criticism and debate. By implication, those talking about things such as 'social contingencies' must be doing something other than studying science. Perhaps, under the guise of 'theoretical speculation', they are reading things into science that belong more to their imaginations than science. As much as there is a pseudoscience of the stars, there can be a pseudoscience of science. Scientists should not be afraid of saying so.

(2) Does Popper's failure have wider, unnoticed implications for scientists? For Popper, science is one of the greatest achievements of our society - one of its unending quests. For those who see the success of science in terms of social contingencies, it is just another social activity - an overprivileged one. Whichever view of science prevails will shape its long-term welfare. Science depends upon public funds. Its success therefore rests on the value politicians and bureaucrats put upon science. But the chances are that they were once as students taught the contemporary, not the popperian, view of science. If this is the case, Popper's failure may have cast a shadow over science and its unending quest.

John R. Skoyles

6 Denning Road,

London NW3 1SU, UK

1. Bondi, H. Nature 358, 363 (1992).

2. Popper, K. R. in in Pursuit of Truth (ed Levinson, P.) 249-289 (Humanities, New York, 1982)

3. Popper, K. R. Conjectures and Refutations (Routledge and Kegan Paul, London, 1963).

\section{How secure?}

SIR - You say (Nature 358, 356; 1992) that plutonium could be stored in "internationally secure repositories". Unfortunately repositories could not be safer than the politicians, dictators or rebels who would look after them.

\section{Richard Baker}

22 Cromwell Road,

Kingston KT2 6RE, UK

\section{Leprosy vaccine}

SIR - K. S. Jayaraman' implies that BCG vaccine has a protective effect against leprosy in Venezuela and that this is "the first demonstrated effect of BCG on leprosy in the New World". But this conclusion is drawn from a retrospective case-control study, which is different from the randomized, doubleblind trial comparing the effect of $\mathrm{BCG}$ alone with that $\mathrm{BCG}$ and Mycobacterium leprae and which did not include a placebo group ${ }^{2}$.

The failure to include a placebo group in this and in the current trial in Malawi is all the more surprising given the contradictory results of the previous BCG trials in Uganda, New Guinea and Burma. Moreover, any useful vaccine should be effective against the borderline and lepromatous multibacillary form of the disease that is considered responsible for transmitting infection.

In the Uganda trial there were no lepromatous cases in the placebo group. The lepromatous rate at the beginning of the Burma trial was predicted to be 23 per cent ${ }^{3}$ but the actual rate in the placebo group was only 3 per cent. The main reason for this very low rate was the rapid decline in case detection because of chemotherapy with dapsone, with a disproportionate fall in the lepromatous rate ${ }^{4}$. In contrast, in the $\mathrm{BCG}$ trial in Karamui, New Guinea, in a population of 5,000 , chemotherapy was not available until 1967 and the incidence rate stayed constant at 5 per 1,000 per year from 1964 to 1971 . There were 19 multibacillary cases during this period $^{5}$ but only 4 from 1972 to 1979 . this decline being due to the effect of chemotherapy which also lowered the incidence in the placebo group 6 .

C. L. Crawford

Department of Anatomy,

Charing Cross and Westminster

Medical School,

Fulham Palace Road,

London W6 8RF, UK

1. Jayaraman, K. S. Nature 356, 373 (1992).

2. Convit. J. et al, Lancet 339, 446-450 (1992).

3. Bechelli, L. M. et al, Bull. WHO 42, 235-281 (1970)

4. Kyaw Lwin \& Zuiderhoek, B. Int. J. Lepr. 43, 125-128 (1975).

5. Scott, G. C., Russell, D. A., Boughton, C. R. \& Vincin D. R. Int. J. Lepr. 44, 110-122 (1976).

6. Bagshawe, A. et al. Bull. WHO 67, 389-399 (1989).

\section{Natural gas}

SIR - Tacitus, the Roman historian, describes in his Annals (Bk. XIII.57) a spectacular natural occurrence that took place in the neighbourhood of Colonia Agrippina in the year $58 \mathrm{AD}$. It is given here in Michael Grant's translation:

But a friendly tribe also, the Ubii, were overwhelmed by a sudden disaster. Flames bursting out of the ground devoured farmhouses, crops, and villages far and wide, right up to the walls of the recently founded settlement named after Agrippina. Neither rain nor river nor any other water could quench the fire. Finally, a few desperate and distraught peasants hurled rocks into the flames, and, as they subsided, advanced and fought them with clubs and other implements, as one would fight wild animals. Finally, they tore off their clothes and heaped them on. The oldest and dirtiest garments were most effective as extinguishers.

The phenomenon has all the characteristics of a leakage of natural gas from underground deposits, which may occur as a result of seismic activity, or natural erosion. The curious detail about the soiled garments is consistent with the way in which flaming natural gas leakages are choked off even today - by depriving the fire of oxygen. Tacitus describes the flames as covering a wide swathe of land around Colonia Agrippina (Cologne), on the western bank of the Rhine. Exploratory drilling may reveal the presence of natural gas deposits in this area.

Jan Sammer

PO Box 219,

Petersburg, New York, 12138, USA 